\title{
Magnesium as a Regulator of Thrombin Formation in Bovine Ovarian Follicular Fluid
}

\author{
Manabu YAMADA, Kayo HIRAKUSHI, Koichi INOUE, Toshitaka HORIUCHI, Junichi SAKAI ${ }^{1)}$, Tadashi OKADA ${ }^{1)}$ \\ and Isamu SUGIE ${ }^{1)}$ \\ School of Bioresources, Hiroshima Prefectural University, Shobara-shi, Hiroshima 727-0023 and ${ }^{1) D e p a r t m e n t ~ o f ~ P h y s i o l o g y, ~ A i c h i ~}$ \\ Medical University, Yazako, Nagakute, Aichi 480-1103, Japan
}

(Received 30 October 1997/Accepted 30 March 1998)

ABSTRACT. In the ovarian follicular fluid (FF) of Holstein cows, calcium (Ca) and magnesium (Mg) levels and their roles on thrombin generation were examined and compared with the blood samples. Total Ca levels in FF increased while the total Mg levels decreased with follicular development from preantral to preovulatory stage of follicles. These changes resulted in Ca values being significantly ( $\mathrm{p}<0.05$ ) higher in FF from the most developed follicles and the $\mathrm{Mg}$ values being significantly higher $(\mathrm{p}<0.05)$ in the least developed follicles. To determine whether the high level of $\mathrm{Mg}$ might function to regulate thrombin generation in $\mathrm{FF}$ as occurs in plasma, the influence of $\mathrm{Mg}$ supplementation of FF from various types of follicles was examined. In FF from small size follicles, Mg accelerated the prothrombin time, an estimation of the overall rate of thrombin production, although a similar effect was not observed in FF from medium and large size follicles. The addition of $\mathrm{Mg}$ to $\mathrm{FF}$ from all sizes of follicles resulted an inhibition in factor $\mathrm{X}$ activation. Since activation of factor $\mathrm{X}$ is a precursor step for thrombin formation it is concluded that $\mathrm{Mg}$ can function as a slow accelerator of thrombin generation in FF from follicles at the antral stage of development. It is likely to have a more important role in regulating the rate of thrombin generation as the follicle develops. - KEY WORDS: bovine, calcium, follicular fluid, magnesium, thrombin generation.

J. Vet. Med. Sci. 60(7): 837-842, 1998

It has recently been shown that bovine and equine ovarian follicular fluid (FF) have the capacity to generate the protease, thrombin, through the tissue factor (TF) pathway [26, 27]. This pathway involves TF combining with Factor VII (FVII) to form a TF-activated FVII complex that converts the inactive factor $\mathrm{X}(\mathrm{FX})$ to activated FX (FXa). In plasma, calcium $(\mathrm{Ca})$ is an essential co-factor in the activation of prothrombin to thrombin because of its involvement to the formation of the FXa-factor Vphospholipid-Ca complex [8]. It has been postulated that a similar mechanism may exist in ovarian follicular fluid [26, 27]. One of the major regulatory proteins of thrombin is antithrombin [20]. The activity of antithrombin in bovine FF is comparatively high compared to the level of other coagulant proteins such as FVII, FX and fibrinogen and appears to be comparable with the level found in bovine plasma [26]. Moreover, antithrombin activity increases with follicle development until the preovulatory stage [23].

In a previous report, both total $\mathrm{Ca}$ and magnesium $(\mathrm{Mg})$ concentrations in bovine follicular fluid remained unchanged over the estrous cycle but increased concentrations were noted with individual follicle development [25]. In bovine $\mathrm{FF}$ the level of $\mathrm{Ca}$ and $\mathrm{Mg}$ appear to be related to hormone levels, specifically androgens in the gonadotropic regulation of ovarian steroidogenesis [25]. The purpose of this study was to find out the function of $\mathrm{Ca}$ and $\mathrm{Mg}$ to thrombin generation in bovine follicular fluid with follicular development. The first objective of this study was to confirm the levels of total $\mathrm{Ca}$, total $\mathrm{Mg}$ and ionized $\mathrm{Ca}$ in FF isolated from bovine follicles at different stages of development using both atomic absorption and spectrophotometric method. The levels of parathyroid hormone (PTH) were also evaluated to determine if there was any connection between the levels of this hormone and $\mathrm{Ca}$ and $\mathrm{Mg}$ level [1]. Because of the potential role of thrombin as a mitogen in follicular development [7], a second objective of the study was to investigate whether $\mathrm{Ca}$ and/or Mg might have a role in thrombin generation during follicular development.

To assess the involvement of $\mathrm{Ca}$ and $\mathrm{Mg}$ level or their concentration ratio to thrombin generation in ovarian follicular fluid, three types of assays were performed: 1) thrombin time assay to determine possible direct effects of $\mathrm{Ca}$ and $\mathrm{Mg}$ on thrombin activity towards the fibrinogen substrate present in follicular fluid, 2) prothrombin time, an overall measurement of thrombin generation in follicular fluid and 3) a specific factor X activity assay since FXa is key activating enzyme in thrombin generation. The results of assays in FF were compared with those of bovine plasma.

\section{MATERIALS AND METHODS}

Blood and follicular fluid samples: Whole blood and ovaries were obtained at a local abattoir from healthy Holstein cows. The blood was collected directly from the carotid artery without anticoagulant for serum preparation and with $3.8 \%$ citrate sodium solution for thrombin generation assays or $10 \mathrm{~g} / \mathrm{l}$ heparin sodium (Daiichi Pure Chem. Co., Tokyo, Japan) solution for mineral assays to obtain plasma. Serum was prepared by incubating the whole blood clot at $4^{\circ} \mathrm{C}$ for $24 \mathrm{hr}$ before aspiration of the supernatant. Plasma was prepared by centrifuging anticoagulated blood at $3,000 \times \mathrm{g}$, for $15 \mathrm{~min}$ at $4^{\circ} \mathrm{C}$. Bovine ovaries were kept at $35^{\circ} \mathrm{C}$ in $0.9 \%$ saline containing $100 \mu \mathrm{g} / \mathrm{m} l$ kanamycin (Kanamycin sulphate Meiji, Meiji Seika Co., Tokyo, Japan) until aspiration of follicular fluid. 
The diameter of the ovarian follicles was measured and the follicles classified into 3 groups according to size (small: $<2 \mathrm{~mm}$, medium: $3-10 \mathrm{~mm}$, large: $11-20 \mathrm{~mm}$ ). FF from 3 groups of small follicle: FF (S), medium follicle: FF (M) and large follicle: FF (L) was aspirated into a plastic syringe with 25 gauge needle and centrifuged at $3,000 \times \mathrm{g}$, for 15 $\min$ at $4^{\circ} \mathrm{C}$ for the removal of a cellular components. These supernatant were stored in small aliquots at $-80^{\circ} \mathrm{C}$ until use.

Reagents: Calcium $(\mathrm{Ca})$ and magnesium $(\mathrm{Mg})$ levels were determined by spectrophotometrical analysis using commercial assay kit (Calcium C-test Wako and Magnesium B-test Wako, Wako Pure Chem. Ind. Ltd., Osaka, Japan) and by atomic absorption analysis compared with $\mathrm{Ca}$ and Mg standard solution (Ca 1000 and Mg 1000, Kanto Chem. Co., Tokyo, Japan). Lanthanum oxide/ $\mathrm{HCl}$ solution was used as diluent for atomic absorption analysis. Bovine thrombin (Thrombin-Mochida, Mochida Pharmaceut. Co., Osaka, Japan) was used for thrombin time (TT) method. Thromboplastin reagent (Simplastin, Warner Rambert-Ono, Japan) was used for prothrombin time (PT) method. Ressell's viper venom (RVV, Sigma Chem. Co., St. Louis, U.S.A.) was used as FX activating enzyme. Chromogenic substrate S-2222 (Chromogenix, Mölndal, Sweden) was used for FX activity assay.

Quantitative analysis of calcium and magnesium: Atomic absorption analysis was used for $\mathrm{Ca}$ and $\mathrm{Mg}$ quantitative analysis. For FF or blood samples, $0.2 \mathrm{~m} l$ were diluted 250 -fold with lanthanum oxide/ $\mathrm{HCl}$ solution. The absorbance of the diluted samples was measured by Polarized Zeeman Atomic Absorption Spectrophotometer (Z-8200, Hitachi, Tokyo, Japan). The amounts of total Ca or $\mathrm{Mg}$ were calculated on the basis of individual standard curves. The $o$-cresolphthalein complexone (OCPC) method was also used as a quantitative method to determine total $\mathrm{Ca}$ volume. For the assay, $0.5 \mathrm{ml}$ of chromogenic reagent solution (0.68 mM OCPC and $69 \mathrm{mM} 8$-quinolinol) was added to $0.02 \mathrm{~m} l$ of sample and $2 \mathrm{~m} l$ of $0.88 \mathrm{M}$ monoethanolamine buffer ( $\mathrm{pH} 11.0)$ mixture. The mixtures were kept at room temperature $\left(22^{\circ} \mathrm{C}\right.$ for $\left.5 \mathrm{~min}\right)$. The absorbance at $575 \mathrm{~nm}$ was measured in a spectrophotometer (V-530, Jasco Corp., Tokyo, Japan) and the amount of total Ca calculated from a standard curve. Total Mg level was also quantified by the xylidyl blue method. Equal volumes $(0.02 \mathrm{ml})$ of sample and chromogenic reagent $(0.1 \mathrm{mM}$ xylylazoviolet I and $0.045 \mathrm{mM}$ glycoletherdiamine tetra acetic acid mixture) were mixed and incubated for $10 \mathrm{~min}$ at room temperature. The absorbance was measured at 520 $\mathrm{nm}$. Ionized $\mathrm{Ca}$ level was determined by ion electrode method using i-STAT (i-STAT Co. Princeton, U.S.A.).

Quantity of PTH: Immuno PTH-C kit (Incstar Co., MN, U.S.A., sensitivity: $0.12 \mathrm{ng} / \mathrm{ml}$ ) was used for the analysis of parathyroid hormone (PTH). For the determination of PTH, $100 \mu l$ of sample FF, bovine serum or standard PTH-C solution (human parathyroid hormone $65-84$ in bovine serum albumin solution) were well mixed with $200 \mu \mathrm{l}$ of antihuman PTH avian serum in glass tubes and incubated at $2-8^{\circ} \mathrm{C}$ for $4 \mathrm{hr}$. After incubation, $200 \mu \mathrm{l}$ of ${ }^{125}$ I-labeled human PTH (65-84) was added and incubation continued at $2-8^{\circ} \mathrm{C}$ for a further $16-24 \mathrm{hr}$. This was followed by the addition of $100 \mu l$ of antichicken serum goat serum to the precipitate and this mixture was then incubated at $2-8^{\circ} \mathrm{C}$ for $2 \mathrm{hr}$. After centrifugation at $2-8^{\circ} \mathrm{C}$ for $20 \mathrm{~min}$ and aspiration, the supernatant was aspirated and the radioactivities in the sample determined from the counts obtained in an auto well-type gamma ray counter. PTH concentration was evaluated on the basis of a standard curve.

Prothrombin time and thrombin time: The PT and the TT assay were measured using a semi-automated coagulation assay system (Fibrosystem, BBL, U.S.A.) [26, 27]. The former was carried out as follows. For the PT assay, $0.1 \mathrm{~m} l$ of sample plasma of FF was incubated for $1 \mathrm{~min}$ at $37^{\circ} \mathrm{C}$ in a prewarmed cuvette at $37^{\circ} \mathrm{C}$ and then $0.2 \mathrm{ml}$ of previously warmed thromboplastin reagent containing $1 / 40 \mathrm{M} \mathrm{CaCl}_{2}$ was added. At the same time, a stopwatch was started and the clotting time recorded. For the TT, the $0.1 \mathrm{~m} l$ of plasma or FF was added to a glass tube $(10 \mathrm{~mm}$ in diameter $)$ prewarmed at $37^{\circ} \mathrm{C}$ followed by $0.1 \mathrm{ml}$ of bovine thrombin solution containing various concentrations of $\mathrm{CaCl}_{2}$ or $\mathrm{MgCl}_{2}$. Each sample was assayed in duplicate and the average clotting time calculated as the coagulation time $(\mathrm{sec})$.

FXa activity: Plasma or FF samples were diluted 25-fold with $0.65 \% \mathrm{NaCl}-50 \mathrm{mM}$ Tris/HCl buffer $(\mathrm{pH} 7.4)$. Diluted sample of $0.2 \mathrm{ml}$ was preincubated for 1 min using a water bath at $37^{\circ} \mathrm{C}$ and mixed with $37.5 \mu \mathrm{l}$ of $166.7 \mathrm{mM} \mathrm{CaCl}_{2}$ $-3.3 \mathrm{u} / \mathrm{m} l \mathrm{RVV}$ mixture solution. This mixture was activated for $3 \mathrm{~min}$ at $37^{\circ} \mathrm{C}$. In the assays where the effect of $\mathrm{Mg}$ was examined, $166.7 \mathrm{mM} \mathrm{MgCl}$ was used in place of 166.7 $\mathrm{mM} \mathrm{CaCl}$ solution. Two volumes of $30 \mathrm{mg} / \mathrm{l} \mathrm{S}-2222$ solution and 1 volume of $1.33 \% \mathrm{NaCl}-50 \mathrm{mM}$ Tris/HCl buffer solution ( $\mathrm{pH} 8.3$ ) were mixed and $0.25 \mathrm{ml}$ of this mixture was added to the activated sample solution. The reaction was allowed to proceed at $37^{\circ} \mathrm{C}$ for $10 \mathrm{~min}$ and then, stopped by $50 \mu l$ of $50 \%$ acetic acid. The absorbance at $405 \mathrm{~nm}$ was measured and the activity calculated from a standard curve prepared with normal bovine plasma and expressed as percent activity. To test for the effect of heparin on FX activation, preliminary experiments were conducted to determine an appropriate inhibitory concentration of heparin in the assay system which was found to be $30,000 \mathrm{u} / l$ of heparin per samples of bovine standard plasma and FF. Heparin $(30,000 \mathrm{u} / l)$ was incorporated into the assay system by mixing with Tris/HCl buffer ( $\mathrm{pH}$ 8.3) for the test of FX activity.

Statistics: All data are expressed as mean \pm the standard error (SE). Data were compared using the Student's t-test for paired or unpaired data using the Sigmaplot computer program (Jandel Scientific, San Rafael, U.S.A.).

\section{RESULTS}

Total $\mathrm{Ca}$, total $\mathrm{Mg}$ and ionized $\mathrm{Ca}$ concentration of serum and ovarian FF in normal Holstein cow were assessed (Table 
Table 1. Calcium and magnesium concentration in serum and ovarian follicular fluid from Holstein cows

\begin{tabular}{|c|c|c|c|c|c|}
\hline \multirow{2}{*}{$\begin{array}{l}\text { Samples } \\
\text { Serum }\end{array}$} & \multicolumn{2}{|c|}{$\begin{array}{r}\text { Total Ca } \\
(\mathrm{mM})\end{array}$} & \multirow{2}{*}{$\begin{array}{c}\begin{array}{c}\text { lonized } \mathrm{Ca} \\
(\mathrm{mM})\end{array} \\
1.00 \pm 0.10\end{array}$} & \multicolumn{2}{|c|}{$\begin{array}{l}\text { Total Mg } \\
\quad(\mathrm{mM})\end{array}$} \\
\hline & $2.38 \pm 0.03$ & $2.70 \pm 0.09$ & & $0.93 \pm 0.04$ & $0.96 \pm 0.04$ \\
\hline $\mathrm{FF}(\mathrm{S})$ & $2.18 \pm 0.04$ & $2.53 \pm 0.09$ & $0.90 \pm 0.01$ & $1.66 \pm 0.06^{*}$ & $1.71 \pm 0.04 *$ \\
\hline $\mathrm{FF}(\mathrm{M})$ & $2.21 \pm 0.04$ & $2.68 \pm 0.06$ & $0.85 \pm 0.03$ & $1.25 \pm 0.04$ & $1.33 \pm 0.04 *$ \\
\hline $\mathrm{FF}(\mathrm{L})$ & $2.72 \pm 0.02^{*}$ & $2.68 \pm 0.04$ & $0.85 \pm 0.03$ & $1.12 \pm 0.04$ & $1.21 \pm 0.04$ \\
\hline
\end{tabular}

Total $\mathrm{Ca}$ and $\mathrm{Mg}$ were assayed by spectrophotometrical method (left) and atomic absorption method (right). Ionized Ca was assayed by ion-electrode method (i-STAT, U.S.A.). FF (S): Small size follicle (diameter $<2 \mathrm{~mm}$ ), FF (M): Medium size follicle (diameter 3-10 mm), $\mathrm{FF}(\mathrm{L})$ : Large size follicle (diameter $=11-20 \mathrm{~mm}$ ). Data were expressed by means and standard error. $\mathrm{n}=20$ (Total $\mathrm{Ca}$ and $\mathrm{Mg}$ ) and $\mathrm{n}=10$ (Ionized $\mathrm{Ca}$ ). * Statistical difference relative to the serum value $(\mathrm{p}<0.05)$.

Table 2. Comparison of ratios of total $\mathrm{Ca}(\mathrm{t}-\mathrm{Ca})$, ionized $\mathrm{Ca}$ (i$\mathrm{Ca}$ ) and total $\mathrm{Mg}(\mathrm{t}-\mathrm{Mg})$ concentration in bovine serum and ovarian follicular fluid

\begin{tabular}{lccc}
\hline Sample & $\mathrm{t}-\mathrm{Ca} / \mathrm{i}-\mathrm{Ca}$ & $\mathrm{t}-\mathrm{Ca} / \mathrm{t}-\mathrm{Mg}$ & $\mathrm{t}-\mathrm{Mg} / \mathrm{i}-\mathrm{Ca}$ \\
\hline Serum & 2.38 & 2.56 & 0.93 \\
FF (S) & $2.42(+1.7 \%)$ & $1.31(-48.8 \%)$ & $1.84(+97.8 \%)$ \\
FF (M) & $2.60(+9.2 \%)$ & $1.77(-39.9 \%)$ & $1.47(+58.1 \%)$ \\
FF (L) & $3.20(+34.5 \%)$ & $2.43(-5.1 \%)$ & $1.32(+41.9 \%)$ \\
\hline
\end{tabular}

Data was calculated from the means values in Table 1 . Values in parentheses represent the $\%$ change relative to the ratio determined in serum (sample ratio/serum ratio $\times 100-100 \%)$. FF $(\mathrm{S})$ : Small size follicle (diameter $<2 \mathrm{~mm}$ ), FF (M): Medium size follicle (diameter=3-10 mm), FF (L): Large size follicle (diameter=11-20 mm).

1). The results of total $\mathrm{Ca}$ assayed by atomic absorption method were expressed a low sensitive and a little higher than the values measured by spectrophotometric method. The values obtained for total $\mathrm{Mg}$ concentrations were similar irrespective of whether the spectrophotometric or atomic absorption methods were used. In FF (S), FF (M) and serum the total $\mathrm{Ca}$ levels assayed by spectophotometric method were not shown the statistical difference, but the total content in FF (L) was significantly higher $(\mathrm{p}<0.05)$ than that of serum. In contrast, ionized Ca levels were similar in the FF from each size of follicle and not significantly different $(\mathrm{p}>0.05)$ from the level found in serum (Table 1). There appeared to be an inverse relationship between the total $\mathrm{Mg}$ and total $\mathrm{Ca}$ in $\mathrm{FF}$ ( $\mathrm{r}=$ $-0.613, \mathrm{~N}=30, \mathrm{p}<0.01)$. In $\mathrm{FF}(\mathrm{S})$ the level of $\mathrm{Mg}$ was almost 2-fold higher than that of serum. In contrast, the total $\mathrm{Mg}$ content in FF $(\mathrm{L})$ was significantly lower $(\mathrm{p}<0.05)$ than the value found in the small follicles. Ionized $\mathrm{Ca}$ was a same level in serum and FF from any developmental stage of follicles. As shown in Table 2, the ratio of total Ca to ionized $\mathrm{Ca}$ or to total $\mathrm{Mg}(\mathrm{Ca} / \mathrm{Mg})$ was the highest in $\mathrm{FF}$ (L) while $\mathrm{Ca} / \mathrm{Mg}$ and total $\mathrm{Mg}$ /ionized $\mathrm{Ca}$ ratio were the lowest in $\mathrm{FF}(\mathrm{S})$. Total $\mathrm{Ca}$ /ionized $\mathrm{Ca}$ ratio was closed to the serum level in $\mathrm{FF}(\mathrm{S})$ while the $\mathrm{Ca} / \mathrm{Mg}$ and total $\mathrm{Mg}$ / ionized $\mathrm{Ca}$ ratio were closer to those of serum level in $\mathrm{FF}$ (L).

No significant differences were found in the PTH levels in serum and FF samples. The mean $\pm \mathrm{SE}$ values for 10 serum samples and for 10 samples each of FF (S), FF (M) and FF (L) were $1.9 \pm 0.1 \mu \mathrm{g} / l, 2.0 \pm 0.1 \mu \mathrm{g} / l, 1.9 \pm 0.2 \mu \mathrm{g} /$ $l, 1.9 \pm 0.3 \mu \mathrm{g} / l$, respectively.

The thrombin time (TT) of bovine plasma without $\mathrm{Ca}$ or $\mathrm{Mg}$ supplementation was $3.19 \pm 0.27 \mathrm{sec}$ (mean $\pm \mathrm{SE}, \mathrm{n}=4$ ) Addition of $\mathrm{Ca}$ up to $50 \mathrm{mM} / \mathrm{l}$ did not significantly ( $>0.05$ ) affect the plasma TT. Likewise, when either $\mathrm{Ca}$ or $\mathrm{Mg}$ was added no significant alterations $(\mathrm{p}>0.05)$ was shown in the TT assay (Table 3). Although there were some trend for changes in the mean TT results, the large variation between samples prevented a statistically significant result from being

Table 3. Thrombin time results for bovine follicular fluid in the presence and absence of added calcium or magnesium

\begin{tabular}{ccccc}
\hline \multirow{2}{*}{$\begin{array}{c}\text { Concentration of } \\
\text { minerals }(\mathrm{mM})\end{array}$} & \multicolumn{2}{c}{$\mathrm{Ca}$} & \multicolumn{2}{c}{$\mathrm{Mg}$} \\
\cline { 2 - 5 } & $\mathrm{FF}(\mathrm{S})(\mathrm{sec})$ & $\mathrm{FF}(\mathrm{L})(\mathrm{sec})$ & $\mathrm{FF}(\mathrm{S})(\mathrm{sec})$ & $\mathrm{FF}(\mathrm{L})(\mathrm{sec})$ \\
\hline 0 & $24.3 \pm 3.3$ & $20.4 \pm 5.0$ & $27.5 \pm 3.6$ & $23.4 \pm 5.7$ \\
0.05 & $30.1 \pm 2.0$ & $23.5 \pm 4.1$ & $35.4 \pm 5.3$ & $22.0 \pm 1.4$ \\
0.5 & $15.5 \pm 1.4$ & $19.6 \pm 4.6$ & $25.5 \pm 3.0$ & $37.4 \pm 4.5$ \\
5 & $25.2 \pm 2.2$ & $18.1 \pm 0.9$ & $22.5 \pm 1.9$ & $34.8 \pm 6.3$ \\
50 & $27.1 \pm 1.5$ & $27.4 \pm 5.8$ & $19.4 \pm 1.8$ & $31.3 \pm 5.0$ \\
500 & $29.6 \pm 3.5$ & $20.2 \pm 5.1$ & $22.1 \pm 3.6$ & $27.5 \pm 3.8$ \\
\hline
\end{tabular}

Data was expressed as mean \pm standard error $(n=4)$. FF $(S)$ : small size follicle (diameter $<2 \mathrm{~mm}$ ), FF (L): large size follicle (diameter $=11-20 \mathrm{~mm}$ ). 


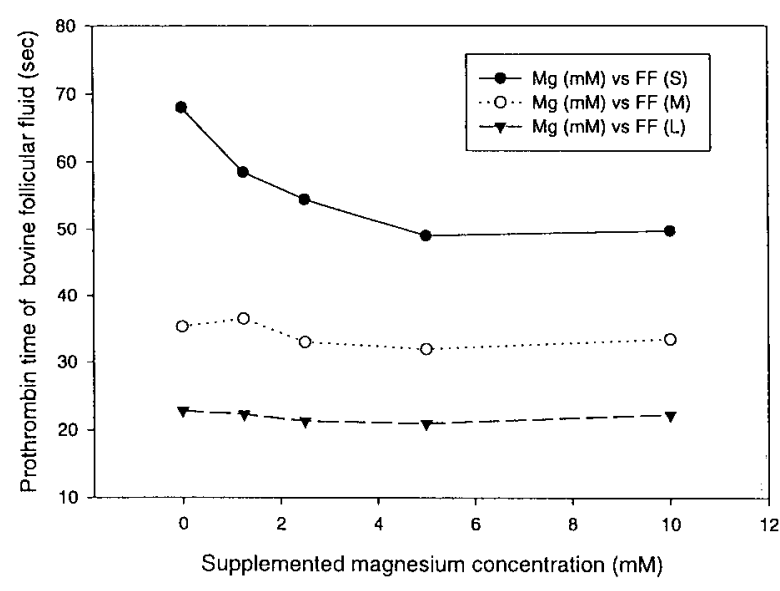

Fig. 1. Effect of magnesium on prothrombin time of bovine ovarian follicular fluid. $\mathrm{Mg}(\mathrm{mM})$ in $\mathrm{FF}(\mathrm{S}), \bigcirc: \mathrm{Mg}(\mathrm{mM})$ in $\mathrm{FF}(\mathrm{M}), \boldsymbol{\nabla}: \mathrm{Mg}(\mathrm{mM})$ in $\mathrm{FF}(\mathrm{L}), \mathrm{n}=10$ per each follicle size groups.

obtained up to $\mathrm{Ca}$ or $\mathrm{Mg}$ concentration of $500 \mathrm{mM} / \mathrm{l}$.

In this study, the PT of bovine plasma $(n=10)$ and follicle samples ( $n=10$ per each follicular size groups) in the absence of additional $\mathrm{Ca}$ or $\mathrm{Mg}$ were as follows, plasma; $13.1 \pm 0.7$ sec $($ mean \pm SE), FF $(\mathrm{S}) ; 56.1 \pm 3.3 \mathrm{sec}, \mathrm{FF}(\mathrm{M}) ; 41.3 \pm 2.1$ sec, FF (L); $35.8 \pm 1.2 \mathrm{sec}$. When the PT of FF (S) sample supplemented with increasing concentrations of $\mathrm{Mg}$, a dosedependent accelerating effect was observed with $\mathrm{Mg}$ concentration up to $5 \mathrm{mM}$ (Fig. 1) while a significant change was not observed in FF (M) and FF (L).

The FXa activity, as assessed by the RVV, was also affected by $\mathrm{Ca}$ or $\mathrm{Mg}$ supplementation in plasma and FF. In FF, FXa activity varied between of FXa 55-83\% plasma activity when $\mathrm{Ca}(22.7 \mathrm{mM}$ as final concentration) was presented in mixture of sample and Ca-RVV solution (Table 4). The lowest activity was detected in FF (S) and the highest in FF (L) with the differences in FXa activity between each follicle developmental stage being statistically different $(\mathrm{p}<0.01)$. When $\mathrm{Mg}(22.7 \mathrm{mM}$ as final concentration) was added to plasma, FXa activity was reduced to $22.5 \pm 1.1 \%$ of the untreated plasma value while the addition of an equal amount of $\mathrm{Mg}$ to each type of FF induced complete inhibition of FXa activity (Table 4). To compare the inhibitory effect of $\mathrm{Mg}$ with that of a known inhibitor, the effect of heparin $(960 \mathrm{u} / l$, the concentration in the mixture of sample and Ca-RVV solution) on the FXa activity in plasma and FF (M) was compared. As shown in Table 4 heparin was a more effective inhibitor in plasma than in FF because the FXa activity in FF was almost twice that of plasma.

\section{DISCUSSION}

Generally, development of ovarian follicles filled with FF is regulated by the gonadotropic hormones follicle stimulating hormone and luteinizing hormone [1]. Bovine and equine $\mathrm{FF}$ have a thrombin generation mechanism
Table 4. Influence of $\mathrm{Ca}, \mathrm{Mg}$ and heparin to factor $\mathrm{X}$ activation by Russell's viper venom (RVV) in bovine plasma and ovarian follicular fluid

\begin{tabular}{lcccc}
\hline Samples & \multirow{2}{*}{$\mathrm{N}$} & \multicolumn{3}{c}{ Activity to the plasma's value (\%) } \\
\cline { 3 - 5 } & & $+\mathrm{Ca}$ & $+\mathrm{Mg}$ & Heparin+Ca \\
\hline Plasma + RVV & 8 & $100.9 \pm 7.1$ & $22.5 \pm 1.1$ & $38.7 \pm 0.8$ \\
FF (S) + RVV & 5 & $54.7 \pm 0.7^{*}$ & 0 & $\mathrm{NT}$ \\
FF (M) + RVV & 5 & $63.1 \pm 0.7^{*}$ & 0 & $66.9 \pm 0.7^{*}$ \\
FF (L) + RVV & 5 & $83.0 \pm 0.8^{*}$ & 0 & $\mathrm{NT}$ \\
\hline
\end{tabular}

a) Data were calculated as a rate $(\%)$ of sample activity to bovine plasma activity and expressed by means \pm standard error. NT: Not tested. *: Statistical differentiation $(\mathrm{p}<0.01)$ to plasma's value. FF (S): Small size follicle (diameter $<2 \mathrm{~mm}$ ), FF (M): Medium size follicle (diameter $=3-10 \mathrm{~mm}), \mathrm{FF}(\mathrm{L})$ : Large size follicle (diameter= 11-20 mm). RVV: Russell's viper venom. Final concentration of heparin in the tested mixture solution was $2.4 \mathrm{unit} / \mathrm{m} l$.

activated by the tissue factor pathway and an inhibitory system regulated by antithrombin $[26,27]$. Compared with the plasma activity, the levels of individual components of the thrombin generating system namely FVII and FX are lower in FF while high level of antithrombin are present. Calcium ion is an essential cofactor on the activation of vitamin K-dependent coagulation factors containing FVII and FX [26, 27]. These factors contain an N-terminal module with 9-12 gamma-carboxyglutamic acid residues (Gla), epidermal growth factor module and C-terminal serine protease module as a binding site of calcium. The Gladependent $\mathrm{Ca}$ binding is a prerequisite for the interaction between these coagulation factor proteins and biological membranes [23]. In this study, total serum Ca concentration were similar to those closely previously reported $[4,16,18$, $19,22]$ as were the ionized Ca concentration $[11,19]$. The ionized $\mathrm{Ca}$ concentration in $\mathrm{FF}$ was found relatively constant at all stages of follicles and approximated the bovine serum level. Because ionized $\mathrm{Ca}$ is generally act a rate limiting factor in thrombin generation in the circulation, the lack of effect of $\mathrm{Ca}$ on thrombin generation in FF in this study support the suggestion that the $\mathrm{Ca}$ levels in $\mathrm{FF}$ are sufficiently high that $\mathrm{Ca}$ is act to rate limiting factor in thrombin generation. This finding may be valid in other species since $\mathrm{Ca}$ level have also reported for human, rabbit, sheep, porcine and bovine FF from preovulatory follicles [10].

Magnesium is recognized as an antagonistic material to $\mathrm{Ca}$ in cattle [1] and it used clinically in the treatment of hypomagnesemia, cardiovascular diseases, critical care and other diseases with hypomagnesemia [2, 6, 24]. Magnesium has no effect on hemostasis when serum levels are less than $3 \mathrm{mM}$ but the coagulation time of whole blood is prolonged when $\mathrm{Mg}$ concentration are greater than $7 \mathrm{mM}$ [12]. The total $\mathrm{Mg}$ level found in this study for bovine serum was $0.93 \pm 0.18 \mathrm{mM} / l$ which is similar to other reports $[4,15$, 18]. However, the $\mathrm{Mg}$ content in FF (S) showed a significant high level compared with the value in plasma and the $\mathrm{Mg}$ level decreased with follicle development with approximately sera being reached in the largest follicles. 
This result agrees with one earlier report [10] and differs from another [25]. Despite the changes in $\mathrm{Ca}$ and $\mathrm{Mg}$ levels in FF at different stage of development, the lack of change in PTH levels in FF indicates that some other factors likely regulates $\mathrm{Ca}$ and $\mathrm{Mg}$ levels during follicular development.

To thrombin time assay, supplementation of $\mathrm{Ca}$ or $\mathrm{Mg}$ was not shown any characteristic effect. Thrombin action for fibrin is $\mathrm{Ca}$ independent [14]. The result on $\mathrm{Mg}$ was also agreed with the case of human FX activation [21]. Therefore, quantitative variation of $\mathrm{Ca}$ and $\mathrm{Mg}$ will not be affected seriously to thrombin activation in FF during development of follicle. Vitamin $\mathrm{K}$ dependent coagulation factors have a functional domain in the $\mathrm{N}$-terminal region. And almost all of the $\mathrm{Ca}$ binding sites are located on gammacarboxyglutamic acid [8]. Calcium binding induces conformational changes in the proteins that facilitates the formation of active enzyme complexes [8]. In the presence of optimum level of Ca, supplementation of FF (S) with a small amount of $\mathrm{Mg}(<5 \mathrm{mM})$ maintained the $\mathrm{Ca} / \mathrm{Mg}$ ratio at the serum level while causing an enhancement of PT (Fig. 1). There was no significant changes in PT times of $\mathrm{FF}(\mathrm{M})$ and $\mathrm{FF}$ (L) with additional $\mathrm{Mg}$ which may be due to the relatively higher ratio of $\mathrm{Ca} / \mathrm{Mg}$. Kinetic studies have shown that $\mathrm{Mg}$ did not promote prothrombin activation to thrombin directly $[5,17]$. However, $\mathrm{Mg}$ can partially substitute for $\mathrm{Ca}$ ion in prothrombin activation [17] under conditions of a low $\mathrm{Ca} / \mathrm{Mg}$ ratio similar to those found in $\mathrm{FF}(\mathrm{S})$. And the $\mathrm{Mg}$ binding to bovine prothrombin $\mathrm{Ca}$ and $\mathrm{Mg}$ affinity site is associated with intermolecular conformation changes and self-association [13]. Furthermore, binding of both ionized $\mathrm{Ca}$ and $\mathrm{Mg}$ to prothrombin are influenced by their relative concentrations, $\mathrm{pH}$ conditions and ion strength [13]. In this study, supplemental addition of a small amount of $\mathrm{Mg}$ to $\mathrm{FF}$, which contains low $\mathrm{Ca}$ and $\mathrm{Ca} / \mathrm{Mg}$ levels compared to serum led to an accelerate of PT. This result indicates that $\mathrm{Mg}$ may only influence thrombin generation under these conditions and is less important as an accelerating act when higher total $\mathrm{Ca}$ and $\mathrm{Ca} / \mathrm{Mg}$ ratios exist such as in $\mathrm{FF}(\mathrm{M})$ and $\mathrm{FF}$ (L).

When the activation of FX by RVV and $\mathrm{Ca}$ was examined the activity in FF was increased from $55 \%$ to $83 \%$ with follicular development compared to bovine plasma. In contrast, when $\mathrm{Mg}$ replaced $\mathrm{Ca}$ in the assay, the FX activation was totally blocked in all FF samples and the FX activation in plasma was reduced $77.5 \%$. This result indicates that $\mathrm{Mg}$ is an effect inhibitor of $\mathrm{FX}$ activation irrespective of the total $\mathrm{Ca}$ or $\mathrm{Ca} / \mathrm{Mg}$ ratios present in $\mathrm{FF}$. The addition of heparin to the FX activation assay in FF did not induce any supplemental inhibitory effect compared to the control sample without heparin. This result indicates that the antithrombin inhibitory activity in FF may function independently of heparin [3] which is distinct from the heparin enhancing effect on antithrombin observed in plasma.

The results of this study indicate that $\mathrm{Ca}$ and $\mathrm{Mg}$ are antagonistic in bovine $\mathrm{FF}$, that the $\mathrm{Ca}$ and $\mathrm{Mg}$ balance changes dynamically with development of follicles and that the ratio of $\mathrm{Ca}$ to $\mathrm{Mg}$ likely influences thrombin formation. When $\mathrm{Ca}$ level and the $\mathrm{Ca} / \mathrm{Mg}$ ratio are low relative to the serum, $\mathrm{Mg}$ is effective in the activation of thrombin generation but as the $\mathrm{Ca} / \mathrm{Mg}$ level rise to approach the serum value, $\mathrm{Mg}$ appears to act as an inhibitor of thrombin generation in FF.

ACKNOWLEDGEMENT. We wish to thank Dr. P. A. Gentry (Ontario Veterinary College, University of Guelph) for helpful discussions.

\section{REFERENCES}

1. Brännström, M, Mikuni, M. and Hedin, L. 1997. Intra-ovarian events during follicular development and ovulation. Hum. Reprod. 12: 51-57.

2. Chester-Jones, H., Fontenot P. and Veit, H. P. 1990. Physiological and pathological effects of feeding high levels of magnesium to steers. J. Anim. Sci. 68: 4400-4413.

3. Danielsson, Å., Raub, E., Lindahl, U. and Björk, I. 1986. Role of ternary complexes, in which heparin binds both antithrombin and proteinase, in the acceleration of the reactions between antithrombin and thrombin or factor Xa. J. Biol. Chem. 261: 15467-15473.

4. Davicco, M. J., Remond, B., Jabet, S. and Barlet, J. P. 1992. Plasma osteocalcin concentrations in cows around parturition. The influence of a regular versus a very short dry period. Reprod. Nutr. Dev. 32: 313-319.

5. Deerfield II, D. W., Olson, D. L., Berkowitz, P., Byrd, P. A., Koehler, K. A., Pedersen, L. G. and Hiskey, R. G. 1987. Mg (II) binding by bovine prothrombin fragment 1 via equilibrium dialysis and the relative roles of $\mathrm{Mg}$ (II) and $\mathrm{Ca}$ (II) in blood. J. Biol. Chem. 262: 4017-4023.

6. Dhupa, N. 1995. Magnesium therapy. pp. 132-133. In: Kirk's Current Veterinary Therapy XII (Bonagura, J. D. and Kirk, R. W. eds.), W. B. Saunders Co., Philadelphia.

7. Forbes, M., Gentry, P. A. and LaMarre, J. 1997. Thrombin and the thrombin receptor in bovine theca cell growth regulation. Endocrinology (in press).

8. Furie, B. and Furie, B. C. 1988. The molecular basis of blood coagulation. Cell 53: 505-518.

9. Gorog, R. H., Hakim, M. K., Thompson, N. W., Rigg, G. A., McCann, D. S. 1982. Radioimmunoassay of serum parathyrin: Comparison of five commercial kits. Clin. Chem. 28: 87-91.

10. Gosden, R. G., Hunter, R. H. F., Telfer, E., Torrance, C., Brown, N. 1988. Physiological factors underlying the formation of ovarian follicular fluid. J. Reprod. Fertil. 82: 813-825.

11. Hallgren, W., Carlstrom, G., Jonsson, G. 1959. Studies on parturient paresis in dairy cows. Determination of calcium ion concentration in bovine serum in different hypocaemic and pseudohypocaemic conditions. Nord. Vet.-Med. 11: 217249.

12. James, M. F. M. and Neil, G. 1995. Effect of magnesium on coagulation as measured by thrombelastography. $\mathrm{Br} . J$. Anaesth. 74: 92-94.

13. Koehler, K. A., Jain, M. K., Gabriel, D. A., Chang, H.-Y. C. and Malhotra, O. P. 1995. Intramolecular domain-domain interactions and intermolecular self-association in bovine prothrombin. A potentiometric and laser light-scattering study. J. Prot. Chem. 14: 537-548. 
14. Leung, L. L. K. and Gibbs, C. S. 1997. Modulation of thrombin's procoagulant and anticoagulant properties. Thromb. Haemostas. 78: 577-580.

15. Mordes, J. P. and Wacker, W. E. C. 1978. Excess magnesium. Pharmacol. Rev. 29: 273-300.

16. Olds, D. and VanDemark, N. L. 1957. Composition of luminal fluids in bovine female genitalia. Fert. Steril. 8: 345-354.

17. Prendergast, F. G. and Mann, K. G. 1977. Differentiation of metal ion-induced transitions of prothrombin fragment 1. $J$. Biol. Chem. 252: 840-850.

18. Riond, J.-L., Kocabagli, N., Spichiger, U. E. and Wanner, M. 1995. The concentration of ionized magnesium in serum during the periparturient period of non-paretic dairy cows. Vet. Res. Commun. 19: 195-203.

19. Roeder, B. L. and Clark, F. D. 1995. Determination of serum ionized calcium concentration in dairy cattle after frozen anaerobic storage. Vet. Clin. Pathol. 24: 44-48.

20. Rosenberg, R. D. 1989. Biochemistry of heparin antithrombin interactions, and the physiologic role of this natural anticoagulant mechanism. Am. J. Med. 87: 3B/3S-9S.

21. Sakiya, F., Yoshida, M., Yamashita, T. and Morita, T. 1996.
Magnesium (II) is a crucial constituent of the blood coagulation cascade: Potentiation of coagulant activities of factor IX by $\mathrm{Mg}^{++}$ions. J. Biol. Chem. 271: 8541-8544.

22. Smith, R. H. 1957. Calcium and magnesium metabolism in calves. Biochemistry 67: 472-481.

23. Sunnerhagen, M., Drakenberg, T., Forsen, S. and Stenflo, J. 1996. Effect of $\mathrm{Ca}^{2+}$ on the structure of vitamin K-dependent coagulation factors. Haemostasis 26: 45-53.

24. Toffaletti, J. 1995. Physiology and regulation. Ionized calcium, magnesium and lactate measurements in critical care settings. Am. J. Clin. Pathol. 104: S88-S94.

25. Wise, T. 1987. Biochemical analysis of bovine follicular fluid: Albumin, total protein, lysosomal enzymes, ions, steroids and ascorbic acid content in relation to follicular size, rank, atresia classification and day of estrous cycle. J. Anim. Sci. 64: 1153-1169.

26. Yamada, M. and Gentry, P. A. 1995. Hemostatic profile of bovine ovarian follicular fluid. Can. J. Physiol. Pharmacol. 73: 624-629.

27. Yamada, M. and Gentry, P. A. 1995. The hemostatic profile of equine ovarian follicular fluid. Thromb. Res. 77: 45-54. 